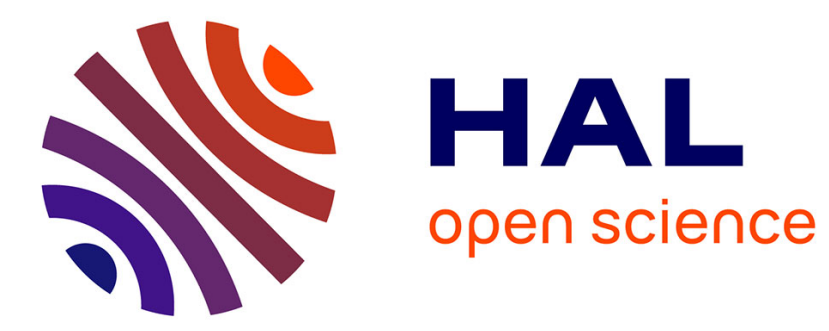

\title{
Wear your mask, but think about deaf students
}

Olivier Pourret, Elodie Saillet

\section{To cite this version:}

Olivier Pourret, Elodie Saillet. Wear your mask, but think about deaf students. Nature, 2020, 586

(7830), pp.629-630. 10.1038/d41586-020-02823-2 . hal-02977774

\section{HAL Id: hal-02977774 \\ https://hal.science/hal-02977774}

Submitted on 26 Oct 2020

HAL is a multi-disciplinary open access archive for the deposit and dissemination of scientific research documents, whether they are published or not. The documents may come from teaching and research institutions in France or abroad, or from public or private research centers.
L'archive ouverte pluridisciplinaire HAL, est destinée au dépôt et à la diffusion de documents scientifiques de niveau recherche, publiés ou non, émanant des établissements d'enseignement et de recherche français ou étrangers, des laboratoires publics ou privés. 


\section{Wear your mask, but think about deaf students}

Masks are vital to contain the spread of coronavirus, but lecturers and universities must find ways to be inclusive, say Olivier Pourret and Elodie Saillet

We are a married pair of associate professors - one a geochemist and the other a structural geologist - living in France. One of our three children is deaf. Both of us will soon be teaching in lecture theatres, and wearing masks in line with French regulations. We support this policy, but we also know how difficult our son would find our lectures, if he were there.

Our son, like many deaf people, is a talented lip reader. What he can't pick up aurally, from what's sometimes called 'residual hearing', he regularly picks up from reading lips. Most masks prevent this mode of understanding among deaf students, who already work very hard to participate and learn in lecture theatres and in schools. Experts estimate that only about 30$40 \%$ of spoken English — and French, our first language — is distinguishable to a talented lip reader in favourable circumstances.

Most people with hearing impairments can and do speak using their natural speech organs, which they have learned to use through speech therapy. But many cannot track or automatically adjust the tone and volume of their voice, so their voice can initially be difficult for people to understand. Awareness grows as one becomes more familiar with the deaf student's speech pattern.

By taking simple action, the scientific community can help deaf students. A few years ago, a deaf student asked us to wear a microphone to amplify and clarify our voices. We have also 
found ways for our son to be accommodated in his learning environment. And we have assembled a list of steps you can take to help deaf students, now and in the future.

- In lectures, use slides and graphical representations of information as much as possible. Think carefully about how you can translate information into a visual format - creating simple figures accompanied by a few printed short sentences, and bold keywords, for example. Overall, try to make your voice and talking the least important aspect of a lecture.

- When you do speak, make your voice as clear as possible: concentrate on articulating every word; make sure you pause regularly; and attenuate your accent, if you have one, as best you can.

- Try to remove all background noise. If individual students are disruptive during lectures or talk through lectures, put a stop to this behaviour: it could make the environment impossible for hearing-impaired students. From experience, a reminder at the start of the lecture should be enough.

- If a student asks a question during a lecture, repeat it before answering, to make sure the entire class heard and understood the question. This will also help with overall comprehension of the class.

- Record your lectures and make them available online for students to download and listen to a second time. Often, institutions do this automatically and will make the necessary tools available — especially now, because of the coronavirus — but, if they don't, ask for equipment, or find your own solutions.

- Consider delivering your lectures over a videoconference platform, or re-recording them for this purpose. Making your face clear in the video will help lip-readers.

- Be careful about sound quality when using YouTube, podcasts or other third-party materials. 
Background sound or music could disturb understanding, so try to select videos with just spoken words (and ideally with subtitles).

- Test masks and find the most 'inclusive' one possible. Transparent face masks make lip reading possible and facial expressions more visible, but they tend not to be cheap (more than $€ 10$, or US\$12, per unit). They can also take some time to get — we ordered some in early August for our son's teachers and only received them mid-September.

- Be willing to learn, change and ask for feedback. Your students will be the people best placed to help you make your lectures more accommodating to them. Set up a way for them to feed thoughts back to you, ideally anonymously so that they feel they can provide honest feedback.

Coronavirus has made life more difficult for many of us, but universities and individual lecturers and teachers should make an effort to include and help all students with their learning.

Olivier Pourret is an Associate Professor of geochemistry at UniLaSalle, Beauvais, France.

Elodie Saillet is an Associate Professor of structural geology at UniLaSalle, Beauvais, France. 